\title{
Can OPEC Cartel Reverse Crude Oil Price Downfall?
}

Ibrahim A. Onour
Department of Business Administration, School of Management Studies, University of Khartoum, Sudan

\begin{abstract}
This paper employs time varying coefficient approach to assess sensitivity of crude oil price change to a number of factors among which change in OPEC crude production and change in US oil production. Our finding indicate crude oil price is inelastic to OPEC production change, with elasticity varying between 0.09 and 0.13 , but elastic to US oil production change with elasticity between 0.99 and 1.05 . This imply on average crude oil price is about 8 times more responsive to US supply expansion than to OPEC supply decisions. As a result, OPEC producers have a limited impact on oil price reversal but the withdrawal of the US high cost shale technology producers from crude oil production at low price levels can be more effective driver of oil price rises in the future. Such low level sensitivity of oil price to change in OPEC supply imply, other things remain unchanged, for oil price to rise from the current $\$ 45$ per barrel to $\$ 70$ per barrel, OPEC cartel needs to cut its current daily production of 27 million barrels by 8 percent.
\end{abstract}

Keywords: OPEC; Crude oil; Price downfall.

\section{Introduction}

The sudden fall of crude oil prices from above $\$ 100$ per barrel in early 2015 to less than $\$ 40$ per oil barrel by the end of the same year indicate oil prices slipping away from the control of the major producers of OPEC group. Research on this issue attributes the recent oil price drop to a number of factors including, increase in global oil supply, and fall of global demand for oil, stronger US dollar price, and random unpredictable factors such as political unrest in major oil producing countries. Statistics on oil production indicate the period (2010 -2014) have witnessed a remarkable increase in oil supply mainly due to the Shale technology revolution which increased US domestic production by around 3.5 million b/d since the start of 2009, which regarded as a record increase for an individual country during the whole history of oil industry ${ }^{1}$. Beside the increased supply of oil in US, the increased refinery capacity in US during the last five years accommodated the excess supply of oil, which may have adverse effect on crude oil price, as refinery capacity expansion can mitigate excess supply constraints, and thus unleash flow of excess production to oil markets ${ }^{2}$.

The fall in the global demand for crude oil in the past few years also viewed as a major factor of recent oil price drop. Energy efficiency and investment in renewable energy, such as solar energy viewed by some analyst as a major factor contributed to demand for oil decline in the global markets. Furthermore, the adoption of more restrictive monetary policy in the two major global consumers of oil, US and China, expected to curb liquidity availability for investors in property, stocks and commodity markets as well.

Also indicated (Novotny, 2012) that there is an inverse relationship between the US dollar exchange rate and the Brent crude oil price. As a result, appreciation of the US dollar in the past few years may have an adverse effect on crude prices. This is because, among other things, since crude oil is priced in US dollar in international commodity markets part of oil export revenue loss due to oil price decrease can be compensated partially by the rising dollar value.

The current paper contributes to existing literature by expanding the determinants of crude oil price change to a number of factors including increase in world demand for crude oil; appreciation in U.S., dollar value; increase in OPEC production; increase in U.S., crude oil production; and a variable reflecting adverse random shocks. To estimate the impact of each of these factors on oil price change time-varying coefficient estimation approach have been employed.

\footnotetext{
${ }^{1}$ The BP statistical review can be accessed at http:www.bp.com/statisticalreview.

${ }^{2}$ Refineries are designed to operate efficiently using specific crudes such that prices of crude oil rises or falls based on the availability of specific types of crude relative to existing refining capacity. Currently much of the world's refining capacity is set up to use light sweet crudes; heavy sour crudes represent much of the unused production capacity in OPEC.
} 
The remaining parts of the paper include the following. Section two highlights literature review, section three discusses basic data analysis, section four illustrates the methodology of the research, section five includes results, and the final section concludes the study.

\section{Literature Review}

Since 1970s oil market models offered analytical framework of oil shocks and their impact on the global economy. The focus of most of these models is to produce projection of future prices or to assess the determinants of oil shocks. MacAvoy (1982) is one of the first models that combines supply and demand with the purpose of determining an equilibrium price that clears oil market. Amano and Van Norden (1993) uses small scale econometric model to forecast oil prices for the years (1986 - 1991). Kaufmann et al. (2004) built a general equilibrium model to understand Saudi government decision making and its influence, as a major producer of oil, on OPEC oil price behavior, and estimated non-OPEC production as a function of geological forecast (based on logistic curve) and oil price effects. (Dees et al. (2007); Dees et al., 2008), analyze short-run determinants of oil prices in OECD and nonOECD countries as a function of income, exchange rates, and technological progress. Kaufmann (2007) indicate there is a non-linear association between oil prices and refinery capacity utilization levels. Huppmann and Holz (2009) employ an optimization model which uses production cost taken from Aguilera et al. (2009) to show that when Saudi Arabia is assumed to be a dominant player in OPEC cartel, it receives oligopolistic profit while the rest of OPEC producers gain competitive profit.

\section{Data Analysis}

Data employed in this study collected from BP statistical Review of World Energy and Index Mundi websites ${ }^{3}$. Variables underlying our analysis include Brent oil price, total crude oil production and consumption, global refineries capacity expansion, and US\$ dollar price per gold. The sample period covers annual time series data from 1965 to 2015. Summary statistics for each of these variables presented in table (2). As indicated by the mean and the minimum/maximum values all variables in the table, especially oil prices and the US\$ value, witnessed high volatility (or shocks) during the sample period. The skewness and high values of kurtosis coefficients indicate the distributions of variables characterized by positive skewness and peakness relative to a normal distribution. The positive skewness results imply a higher probability for increases above its mean values during the sample period. The Jarque-Bera (JB) test statistic provides evidence to reject the null-hypothesis of normality for all variables. Phillip-Perron (PP) test results indicate, while there is evidence of random walk behavior for all variables at levels, but there is evidence of stationarity of all variables at the first difference. Thus, to capture the random walk behavior of each variable, residuals from $\mathrm{AR}(\mathrm{p})$ process for each variable (at the level) need to be estimated.

Table-1. Summary statistics

\begin{tabular}{|c|c|c|c|c|c|c|}
\hline & $\begin{array}{l}\text { Oil price } \\
\text { US\$/b }\end{array}$ & $\begin{array}{l}\text { Production } \\
(000 \text { b/d })\end{array}$ & $\begin{array}{l}\text { Consumption } \\
(000 \text { b/d })\end{array}$ & $\begin{array}{l}\text { US\$ Per } \\
\text { oz gold }\end{array}$ & $\begin{array}{l}\text { OPEC } \\
\text { production } \\
(000 \text { b/d }) \\
\end{array}$ & $\begin{array}{l}\text { US production } \\
(000 \mathrm{~b} / \mathrm{d})\end{array}$ \\
\hline Mean & 48.39 & 65019 & 65883 & 414 & 26668 & 9129 \\
\hline Min/ & 10.7 & 31798 & 30811 & 34 & 13922 & 6783 \\
\hline Max & 115 & 86754 & 91331 & 1668 & 37427 & 11297 \\
\hline Skewness: & 1.04 & 2.39 & 3.26 & 0.33 & 0.60 & 1.88 \\
\hline Ex.Kurtosis: & 3.44 & 11.54 & 17.4 & 3.93 & 3.51 & 8.0 \\
\hline $\begin{array}{l}\text { JB test } \\
\text { p-value }\end{array}$ & $\begin{array}{l}26.5 \\
0.000\end{array}$ & $\begin{array}{l}259.9 \\
0.000\end{array}$ & $\begin{array}{l}573 \\
0.000\end{array}$ & $\begin{array}{l}24.7 \\
0.000\end{array}$ & $\begin{array}{l}21.8 \\
0.000\end{array}$ & $\begin{array}{l}130 \\
0.000\end{array}$ \\
\hline PP test (level) & -6.1 & -8.81 & -8.48 & -2.67 & -5.4 & -0.97 \\
\hline PP test ( $1^{\text {st }}$ difference $)$ & $-51.3^{*}$ & $-45.3^{*}$ & $-45.4^{*}$ & $-45^{*}$ & $-40.9^{*}$ & $-38.5^{*}$ \\
\hline
\end{tabular}

*significant at $5 \%$ significance level.

\section{Methodology}

As global oil market witnessed in the past decade a remarkable shocks, a potential candidate for capturing structural change in coefficent values is time-varying linear regression models. For that purpose in this paper we employed the Flexible Least Squares (FLS) method which designed to capture sinusoidal time-varying coefficient patterns. The dynamic equations governing the motion of the coefficients in most cases is unknown, but in other estimation methods (i.e OLS) it is assumed that change in coefficients evolve only slowly over time. In this regard two types of model specification errors can be considered for the estimates of coefficients in FLS approach. Residual measurement errors given by the deviation of the estimated values of the dependent variable from the observed values; and residual dynamic errors, given by the discripancy between successive coefficient values. The FLS solution is the sequence of coefficients estimate that yield the minimum sums of squared residual measurement error, and squared dynamic errors. More specifically, consider a linear regression model with time-varying coefficients:

\footnotetext{
${ }^{3}$ The BP statistical review can be accessed at http:www.bp.com/statisticalreview.
} 


$$
Y_{t}=X_{t}^{\prime} \beta_{t}+e_{t} \quad \text { for } t=1,2, \ldots . N
$$

Where $\mathrm{Y}_{\mathrm{t}}$ is a column vector of oil price at time $\mathrm{t}, \mathrm{X}_{\mathrm{t}}$ is a matrix of explanatory variables of $\mathrm{nXq}$ order where $\mathrm{q}$ is the number of explanatory variables, and $e_{t}$ is a random error terms. The FLS method developed by Kalaba and Tesfatsion (1989) finds the time paths of the coefficients which minimize the incompatibility cost function:

$$
\begin{gathered}
C(\beta ; \delta, N)=\frac{1}{1-\delta}\left[\delta \sum_{t=1}^{N-1}\left(\beta_{t+1}-\beta_{t}\right)^{\prime} \quad\left(\beta_{t+1}-\beta_{t}\right)+(1-\delta) \sum_{t=1}^{N}\left(Y_{t}-X^{\prime}{ }_{t} \beta_{t}\right)^{2}\right. \\
=\frac{1}{1-\delta}\left[\delta r_{D}^{2}(\beta ; N)+(1-\delta) r_{M}^{2}(\beta ; N)\right]
\end{gathered}
$$

Where $\beta=\left(\beta_{1}, \beta_{2}, \ldots . \beta_{N}\right)$ is the time-path of coefficient vectors, $r_{D}^{2}$ is the sum of squared residual dynamic errors, $r_{M}^{2}$ is the sum of squared residual measurement errors, and $\delta \in(0,1)$ is smoothness weight. The OLS extreme point occurs when $\delta=1$, and equal weights apply when $\delta=0.5$. The FLS solution is conditional on the choice of the smoothness parameter.

A strength of FLS is its ability to capture turning points and other systematic time-variation in the coefficients. Thus, FLS is an appropriate measure of non-linear regression even in cases of parameters nonlinearity that include elliptical and sinusoidal behavior of coefficients. FLS can be compared with other structural break test models such as Chow test and CUSUM of recursive residual tests. The Chow test requires the specification of a break-point and assumes coefficient constancy over a sub-period. The CUSUM test suitable for global stability test, but compared to FLS, does not identify the sources of instability. Another merit of FLS is that requires no distributional assumptions on the error terms.

\section{Results}

To assess the long-term association between oil price change and OPEC and US crude oil production changes, we employed the Autoregressive Distributed Lag (ARDL) test procedure developed by Pesaran and Shin (2001). An important merit of the bound test, unlike other multivariate conintegration tests, such as that of Johansen and Juselius (1990), it does not require cointegration of the same order of all variables, in other words it is applicable regardless of whether the independent variables are stationary, $\left(\mathrm{I}(0)\right.$, or random walk, $\mathrm{I}(1)^{4}$.

The cointegration result of crude oil price with the five variables: change in world demand for crude oil; change in US dollar price; change in OPEC crude oil production; and change in US crude production indicate ARDL test result of 4.46 , which reject the null of no cointegration at the $5 \%$ significance level.

FLS estimation results of equation (1), based on log transformation of all variables, reported in table (2) reveal the mean coefficient values for each of the explanatory variables as well as the standard deviation and the coefficient of variation statistics. FLS mean coefficients indicate, on the demand side, $1 \%$ increase in world demand for crude oil, push crude price upward by $2.7 \%$ and 1 percent in US dollar appreciation against gold (or other convertible currencies), reduce crude price by $0.08 \%$. However, on supply side, $1 \%$ increase in OPEC production, reduce crude price by $0.12 \%$, and $1 \%$ increase in US crude oil production reduce crude price by $1.03 \%$. The last result indicate crude oil price is more responsive to US supply expansion than to OPEC supply decisions. The effect of adverse random effects on crude oil price is estimated as $1.07 \%$. The proximity of the two coefficients of $1.03 \%$ and $1.07 \%$ is consistent with the observation that the drop in oil production due to political unrest in countries like Libya, Syria, and Iraq is almost equal to the increase in the US Shale production in the past five years.

Table-2. FLS parameter estimates

\begin{tabular}{l|c|l|l}
\hline $\begin{array}{l}\text { explanatory } \\
\text { variables* }\end{array}$ & $\begin{array}{l}\text { Coefficients } \\
\text { (min/max) } \\
\text { mean }\end{array}$ & Std. deviation & $\begin{array}{l}\text { coefficient } \\
\text { of variation }\end{array}$ \\
\hline $\begin{array}{l}\text { X1 } \\
\text { mean }\end{array}$ & $\begin{array}{c}(2.69 \text { to } 2.72) \\
2.70\end{array}$ & 0.008 & 0.003 \\
\hline $\begin{array}{l}\text { X2 } \\
\text { mean }\end{array}$ & $\begin{array}{c}(-0.17 \text { to }-0.03) \\
-0.08\end{array}$ & 0.04 & 0.058 \\
\hline $\begin{array}{l}\text { X3 } \\
\text { mean }\end{array}$ & $\begin{array}{c}(-0.13 \text { to }-0.09) \\
-0.12\end{array}$ & 0.02 & -0.18 \\
\hline $\begin{array}{l}\text { X4 } \\
\text { mean }\end{array}$ & $\begin{array}{c}(-1.05 \text { to }-0.99) \\
-1.03\end{array}$ & 0.02 & -0.02 \\
\hline $\begin{array}{l}\text { E } \\
\text { mean }\end{array}$ & $\begin{array}{c}(0.98 \text { to } 1.14) \\
1.07\end{array}$ & 0.04 & 0.04 \\
\hline Constant & 0.01 & 0.15 & 11.4 \\
\hline
\end{tabular}

*Since double log function form is specified, the regression coefficients represent elasticities. $* \mathrm{X} 1=$ increase in world demand; $\mathrm{X} 2=$ appreciation in US $\$$ price per gold oz;

$\mathrm{X} 3=$ increase in OPEC production; $\mathrm{X} 4=$ increase in US production; $\mathrm{E}=$ adverse random shocks.

\footnotetext{
${ }^{4}$ But inconclusive if the order of integration of the variables of order two, or more
} 


\section{Concluding Remarks}

To explain the causes of recent crude oil price falls in this paper we employed Flexible Least Squares method taking change in crude oil price as dependent variable and independent variables including change in world demand; change in US dollar price; change in OPEC supply ; change in non-OPEC supply ; and finally a random walk variable (E) reflecting non-predictable events ${ }^{5}$.

FLS estimation results indicate, on the demand side, 1 percent increase in world demand for crude oil, increase crude price by 2.7 percent and 1 percent US dollar appreciation against gold (or other convertible currencies), reduce crude price by 0.08 percent. On supply side, 1 percent increase in OPEC production, reduce crude price by 0.12 percent, and also one percent increase in US crude oil production reduce crude price by 1.03 percent, indicating that crude oil price is more responsive to US supply expansion than to OPEC supply decisions. The effect of adverse random effects on crude oil price is estimated at 1.07 percent. The proximity of the two coefficients of 1.03 percent and 1.07 percent is consistent with the observation that the drop in oil production due to political unrest in countries like Libya, Syria, and Iraq is exactly equal to the increase in the US Shale production in the past five years. The sensitivity of oil price to change in OPEC supply indicate, all other things remain unchanged, for oil price to rise from the current $\$ 45$ per barrel to $\$ 70$ per barrel, OPEC cartel needs to cut its current daily production of 27 million barrels by 8 percent, which is about 2.2 million barrels per day.

\section{References}

Aguilera, R., Eggert, R., Lagos, G. and Tilton, J. (2009). Depletion and future availability of petroleum resources. The Energy Journal, 30(1): 141-74.

Amano, R. and Van Norden, S. (1993). Oil prices and the rise and fall of the U.S., real exchange rate. Working Papers, Bank of Canada, 93(15): 1-10.

Dees, S., Karadeloglou, P., Kaufmann, R. and Sanchez, M. (2007). Modelling the world oil market, assessment of a quarterly econometric model. Energy Policy, 35(1): 178-91.

Dees, S., Gasteuit, A., Kaufmann, R. and Mann, M. (2008). Assessing the factors behind oil price change" Working Papers Series, No.855, European Central Bank.

Huppmann, D. and Holz, F. (2009). A model for the global crude oil market using a multi-pool MCP approach, discussion paper 869, Institute for Economic Research, DIW Berlin, Germany.

Johansen, S. and Juselius, K. (1990). Maximum likelihood estimation and inference on cointegration with application to the demand for money. Oxford Bulletin of Economics and Statistics, 52(2): 169-209.

Kalaba, R. and Tesfatsion, L. (1989). Time-varying linear regression via flexible least squares. Computers and Mathematics with Applications, 17(08): 1215-45.

Kaufmann, R. K. (2007). US refining capacity: implications for environmental regulations and the production of alternative fuels, CEES Working paper.

Kaufmann, R. K., Dees, P., Karadeloglou and Sanchez, M. (2004). Does OPEC matter? an econometric analysis of oil prices. The Energy Journal, 25(4): 67-90.

MacAvoy, P. (1982). Crude oil price as determined by OPEC and market fundamentals. Publisher: Ballinger.

Novotny, F. (2012). The link between the Brent crude oil price and the US dollar exchange rate. Prague Economic papers: $220-32$.

Pesaran, H. and Shin, Y. (2001). Bounds testing approaches to the analysis of level relationships. Journal of Applied Econometrics, 16(3): 289-326.

\footnotetext{
${ }^{5}$ Since Phillips-Perron test show oil price is non-stationary at the level, then random walk variable has been measured using the residual error terms resulting from the $\mathrm{AR}(1)$ process of oil price.
} 